\title{
Management of Alterneria cucumerina var. cyamopsidis through Plant Extracts, Bio products and Fungicides in-vitro and in-vivo
}

\author{
Anupriya*, Rajni Singh Sasode and Prahlad \\ Department of Plant Pathology, Rajmata Vijayaraje Scindia Krishi Vishwavidyalaya, \\ Gwalior-474002,(M.P.), India \\ *Corresponding author
}

\begin{tabular}{l} 
Key w o r d s \\
Cluster bean, Plant \\
extracts, Bio \\
products, \\
Fungicides \\
\hline Article Info \\
\hline $\begin{array}{l}\text { Accepted: } \\
\text { 20 February } 2020 \\
\text { Available Online: } \\
\text { 10 March } 2020\end{array}$ \\
\hline
\end{tabular}

\section{A B S T R A C T}

Laboratory studies were conducted to study the effect of six botanicals (neem leaf extract, garlic bulb extract, eucalyptus leaf extract, castor oil, mustard oil, neem oil) and two bio products (vermin wash, cow urine) were evaluated against against A. cucumerina var. cyamopsidis under in-vitro condition. Maximum mycelium inhibition was recorded in Garlic bulb extract followed by Neem leaf extract and Cow urine. Nine fungicides [Difenconazole (25EC), Chlorothalonil (75WP), Carbendazim 12\% + Mancozeb 63\%WP, Mancozeb (75), kitazin (48\%EC), Hexaconazole 50\%, Tebuconazole 50\% + Trifloxystrobin 25\%, Azoxystrobin, Tricyclazole] evaluated against Alternaria cucumerina var. cyamopsidis under in-vitro condition. All the fungicide inhibited the mycelial growth at all concentrations of fungicides. Difenconazole (100\%), Tebuconazole $50 \%$ + Trifloxystrobin 25\% (100\%) and Azoxystrobin (100\%), completely inhibited the growth at 500ppm concentration. A field experiment conducted to know the efficacy of four botanicals (Neem leaf extract, Garlic bulb extract, Neem oil, Cow urine) and six fungicides (Carbendazim 12\% + Mancozeb 63\%WP, Difenconazole (25EC), Tebuconazole 50\% + Trifloxystrobin 25\%, Chlorothalonil (75WP), Azoxystrobin) against Alternaria blight in foiler disease. Among the treatments, minimum disease incidence was recorded in Difenconazole (25EC), followed by Carbendazim 12\% + Mancozeb 63\%WP, Chlorothalonil (75WP) and Azoxystrobin. Among the botanicals, minimum disease incidence was recorded in Garlic bulb extract.

\section{Introduction}

Clusterbean [Cyamopsis tetragonoloba (L.) Taub] is an important leguminous crop of kharifseason in arid and semi-arid region of India. It is a very hardy and drought tolerant crop. Alternaria blight caused by Alternaria cucumerina var. cyamopsidis, which is a major foliar disease of clusterbean in northern
India.. In India, this crop is mostly grown in the state of Rajasthan, Haryana, Punjab, U.P. and M.P. About $80 \%$ area of the state is in gird zone. In India, clusterbean cultivation is accounted for about 75 percent of global trade and 80 percent to total guar production in the world (Swamy and Naveena, 2015). In M.P., clusterbean is cultivated as pure crop in 75280 hectares and as mixed crop in 54782 hectares 
area. Seeds of cluster bean contain 28 to 33 per cent gum and its use in almost all types of industries viz., textile, paper, petroleum, pharmaceuticals, food processing, cosmetics, mining, explosives and oil drilling, etc. Besides, it increases fertility of soil by fixing considerable amount of atmospheric nitrogen. India is the leading country in the world, where it occupies 52-55.8 lakh hectares with annual production of 28.32 lakh tonnes (Anonymous, 2017-18). India produces 85 per cent of total guar production in the world followed by 15.6 per cent by Pakistan and 12.1 per cent by USA, Brazil and others. Little attention has been paid on Alternaria blight of cluster bean caused by $A$. cucumerina var. cyamopsidis which has become a serious problem in hampering the production in all the clusterbean growing areas especially in rainfed condition. Symptoms of blight appeared on cotyledons, leaves, petioles, stems and pods but mainly. Dark brown more or less circular to irregular lesions up to $10 \mathrm{~mm}$ diameter were observed on leaves. The lesions turned grayish to dark brown lines inside the lesions. In some lesions distinct darker marginal ridges were seen, also lesions with and without chlorotic halo. At times, several lesions coalesce involving most of the leaf surface and such leaves with petiole infection get defoliated. Similar types of lesions were also seen on cotyledons. On petiole and stem, the lesions were sunken and enlarged up to $10-15 \mathrm{~mm}$. lesions on pod were small, brown to black with concentric zonation. Orellana and Simmons (1965) observed two types lesion occur on guar leaves (A) brown, more or less circular lesions up to $10 \mathrm{~mm}$ diameter with distinct, darker marginal ridges and (B) medium brown, spreading lesions without definite marginal ridges and with or without chlorotic halos. Stem lesions appear to develop more rapidly after defoliation. Brown to black lesions is superficial to sunken, up to $5 \mathrm{~mm}$ in diameter, with or without distinct ridges.
Early pod attack by Alternaria appears to interfere with seed development. Symptoms on leaves were small, circular, necrotic spots that develop quickly forming typical concentric rings. Later, these spots coalesce and cause blighting of leaves. The spots were initially light brown which later turned dark brown. On stems, spots were sunken, with concentric rings. In severe infection, defoliation and drying of infected leaves, branches and flower buds was observed.Application of biological agents and extract is eco-friendly and a sustainable approach apart from being a promising alternative to fungicide application. In the absence of resistant cultivars, chemical fungicides provide the most reliable means of disease control. The present study was aimed at determining a cost effective management of Alternaria leaf spot.

\section{Materials and Methods}

The experiment was laid out in a complete randomized design (CRD) with nine treatments including untreated control and replicated thrice with three concentrations. Eight bio product viz., Neem leaf extract, Garlic bulb extract, Eucalyptis leaf extract, Castor oil, Mustard oil, Neem oil, Cow urine and Vermi wash were evaluate against $\mathrm{A}$. cucumerina var. cyamopsidis. The present study was undertaken in the laboratory conditions to find out their relative efficacy to inhibit the radial growth of the pathogen on PDA medium by poisoned food technique (Nene and Thapliyal 1979). The calculated quantity of bio-product and bio extracts were added to potato dextrose agar (PDA), mixed thoroughly and poured into sterilized Petriplates and allowed to solidify. After solidification, each plate was inoculated with a $5 \mathrm{~mm}$ diameter disc obtained from an actively growing margin of $A$. cucumerina colony on PDA. The Petri dishes were incubated at $25+1^{\circ} \mathrm{C}$ in $\mathrm{BOD}$ incubator and 
allow to growth. The data of efficacy of bio product against A. cucumerina var. Cyamopsidis was recorded after 7 days after inoculation (DAI) for growth of pathogen at $25 \pm 1^{\circ} \mathrm{C}$. Per cent growth inhibition over control was calculated by the following formula suggested by Vincent (1947) and confirmed by Hegde et al., (2014).

Per cent growth inhibition =

$$
\frac{C-T}{C} \times 100
$$

Where as,

$\mathrm{C}=$ Mycelial growth of A. cucumerina var. cyamopsidis in control ( $\mathrm{mm})$

$\mathrm{T}=$ Mycelial growth of $A$. cucumerina var. cyamopsidis in treatment $(\mathrm{mm})$

Field experiments was conducted with clusterbean germplasm were laid out during kharif 2018-19 at experimental Field, College of Agriculture, Gwalior. The crop was sown on $21^{\text {th }}$ July, 2018 and keeping plot size $3 \times 5 \mathrm{~m}^{2}$ with $30 \times 15 \mathrm{~cm}$ row to row and plant to plant spacing following Randomized Block Design with three replications.

The fungicide, bio product and plant extract which performed better under in-vitro condition against Alternaria cucumerina var. cyamopsidis were again tested under in-vivo conditions to test their efficacy to manage the disease. The effective fungicide (Carbendazim 12\% + Mancozeb 63\%WP, Difenconazole (25EC), Tebuconazole 50\% + Trifloxystrobin 25\%, Chlorothalonil (75WP) and Azoxystrobin) bio-products (Neem leaf extract, Garlic bulb extract and Neem oil) and plant extracts (Cow urine) were sprayed at just appearance of disease. Two subsequent sprays of chemical and plant extracts were given at 10 days interval. The spraying was done using manually operated high volume (Knapsack) sprayer.
Disease intensity was recorded after 7-10 days of second spray. Per cent disease control was calculated by following formula:

Per cent disease control $=\quad \frac{\mathrm{C}-\mathrm{T}}{\mathrm{C}} \times 100$

Where,

$\mathrm{C}=$ Disease intensity in control

$\mathrm{T}=$ Disease intensity in treatment

\section{Results and Discussion}

Evaluation of botanicals and bio-products against Alterneria cucumerina var. cyamopsidis in-vitro

To explore the possibility of substituting fungicide with other eco-friendly products, eight plant extracts/bio products (neem leaf extract, garlic bulb extract, eucalyptus leaf extract, castor oil, mustard oil, neem oil, cow urine, vermin wash) of different concentrations viz., (2, 5 and 10\%) were tested in-vitro against the mycelium growth of Alterneria cucumerina var. cyamopsidis .

At $10 \%$ concentration the minimum mycelium growth was found in garlic bulb extract $(28.00 \mathrm{~mm})$ followed by neem leaf extract $(33.33 \mathrm{~mm})$, neem oil $(40.33 \mathrm{~mm})$, cow urine $(36.67 \mathrm{~mm})$, mustard oil (43.00 $\mathrm{mm})$, eucalyptus leaf extract $(48 \mathrm{~mm})$, castor oil $(51.67 \mathrm{~mm})$, vermi wash $(57.67 \mathrm{~mm})$ while the maximum mycelial growth was recorded in control $(82.67 \mathrm{~mm})$.

In general all plant extracts showed antifungal activity against the pathogen at all concentrations. The effectivity of the extracts increases with increase in concentration of extracts and the minimum growth of fungus was recorded in garlic bulb extract at all concentrations which was significantly superior over rest of the plant extract in respect of mycelial growth. 
Table.1 In-vitro evaluation of bio-products and plant extracts against mycelial growth of $A$. cucumerina var. cyamopsidis at different concentration

\begin{tabular}{|c|c|c|c|c|c|c|c|}
\hline \multirow[t]{3}{*}{ S. no } & \multirow{3}{*}{$\begin{array}{l}\text { Plant extract / } \\
\text { bio products }\end{array}$} & \multicolumn{6}{|c|}{ Mycelium growth (mm) and per cent inhibition at different concentrations } \\
\hline & & \multicolumn{2}{|c|}{$2 \%$} & \multicolumn{2}{|c|}{$5 \%$} & \multicolumn{2}{|c|}{$10 \%$} \\
\hline & & $\begin{array}{c}\text { Mycelial } \\
\text { growth }(\mathbf{m m})\end{array}$ & $\begin{array}{c}\text { Per cent } \\
\text { inhibition }\end{array}$ & $\begin{array}{c}\text { Mycelial } \\
\text { growth }(\mathbf{m m})\end{array}$ & $\begin{array}{c}\text { Per cent } \\
\text { inhibition }\end{array}$ & $\begin{array}{c}\text { Mycelial } \\
\text { growth }(\mathbf{m m})\end{array}$ & $\begin{array}{l}\text { Per cent } \\
\text { inhibition }\end{array}$ \\
\hline 1 & Neem leaf extract & 43.00 & 48.38 & 40.33 & 51.60 & 33.33 & 59.67 \\
\hline 2 & Garlic bulb extract & 37.33 & 55.17 & 33.67 & 59.57 & 28.00 & 66.11 \\
\hline 3 & Eucalypus leaf extract & 57.00 & 31.78 & 53.33 & 35.98 & 48.00 & 41.92 \\
\hline 4 & Castor oil & 58.67 & 29.58 & 54.67 & 34.39 & 51.67 & 37.47 \\
\hline 5 & Mustard oil & 56.33 & 32.39 & 50.00 & 40.00 & 43.00 & 47.97 \\
\hline 6 & Neen oil & 48.67 & 41.57 & 44.00 & 47.19 & 40.33 & 51.23 \\
\hline 7 & Cow urine & 49.67 & 40.37 & 46.33 & 44.39 & 36.67 & 55.67 \\
\hline 8 & Vermi wash & 66.33 & 20.39 & 61.33 & 26.36 & 57.67 & 30.21 \\
\hline 9 & Control & 83.33 & 0.00 & 83.33 & 0.00 & 82.67 & 0.00 \\
\hline \multicolumn{2}{|l|}{ SEm \pm} & 0.59 & & 1.13 & & 0.56 & \\
\hline & C.D.at 5\% & 1.77 & & 3.39 & & 1.66 & \\
\hline
\end{tabular}


Table.2 In-vitro evaluation of fungicides on mycelial growth of Alternaria cucumerina var. cyamopsidis

\begin{tabular}{|c|c|c|c|c|c|c|c|c|c|c|c|}
\hline \multirow[t]{3}{*}{ S.no } & \multirow[t]{3}{*}{ Fungicide } & \multicolumn{10}{|c|}{ Mycelium growth (mm) and per cent inhibition at different concentrations } \\
\hline & & \multicolumn{2}{|c|}{100 PPM } & \multicolumn{2}{|c|}{200 PPM } & \multicolumn{2}{|c|}{300 PPM } & \multicolumn{2}{|c|}{400 PPM } & \multicolumn{2}{|c|}{500 PPM } \\
\hline & & $\begin{array}{l}\text { Mycelial } \\
\text { growth } \\
(\mathrm{mm})\end{array}$ & $\begin{array}{l}\text { Per cent } \\
\text { inhibition }\end{array}$ & $\begin{array}{l}\text { Mycelial } \\
\text { growth } \\
(\mathbf{m m})\end{array}$ & $\begin{array}{l}\text { Per cent } \\
\text { inhibition }\end{array}$ & $\begin{array}{c}\text { Mycelial } \\
\text { growth } \\
(\mathbf{m m})\end{array}$ & $\begin{array}{l}\text { Per cent } \\
\text { inhibition }\end{array}$ & $\begin{array}{c}\text { Mycelial } \\
\text { growth } \\
(\mathbf{m m})\end{array}$ & $\begin{array}{l}\text { Per cent } \\
\text { inhibition }\end{array}$ & $\begin{array}{l}\text { Mycelial } \\
\text { growth } \\
(\mathbf{m m})\end{array}$ & $\begin{array}{l}\text { Per cent } \\
\text { inhibition }\end{array}$ \\
\hline 1 & Difenconazole(25EC) & 8.33 & 90.31 & 4.79 & 94.55 & 1.67 & 98.14 & 0.00 & 100.00 & 0.00 & 100.00 \\
\hline 2 & Chlorothalonil (75WP) & 22.67 & 73.65 & 18.67 & 78.79 & 13.67 & 84.80 & 8.33 & $90 . .73$ & 4.33 & 95.18 \\
\hline 3 & $\begin{array}{l}\text { Carbendazim 12\%+ } \\
\text { Mancozeb 63\%WP }\end{array}$ & 25.67 & 70.16 & 21.67 & 75.37 & 16.67 & 81.47 & 12.67 & 85.92 & 7.67 & 91.88 \\
\hline 4 & Mancozeb(75) & 33.67 & 60.84 & 27.67 & 68.55 & 21.67 & 75.91 & 14.33 & 84.07 & 9.67 & 89.25 \\
\hline 5 & kitazin $(48 \% \mathrm{EC})$ & 47.33 & 45.16 & 43.33 & 50.75 & 40.67 & 54.80 & 36.33 & 59.62 & 32.66 & 63.71 \\
\hline 6 & Hexaconazole $50 \%$ & 39.33 & 54.46 & 35.67 & 59.46 & 31.33 & 65.18 & 26.67 & 70.36 & 22.67 & 74.80 \\
\hline 7 & $\begin{array}{l}\text { Tebuconazole } 50 \%+ \\
\text { Trifloxystrobin } 25 \%\end{array}$ & 16.67 & 80.62 & 13.67 & 84.47 & 9.33 & 89.62 & 0.00 & 100.00 & 0.00 & 100.00 \\
\hline 8 & Azoxystrobin & 15.67 & 82.09 & 11.67 & 86.74 & 9.67 & 89.25 & 4.33 & 95.18 & 0.00 & 100.00 \\
\hline 9 & Tricyclazole & 53.67 & 37.59 & 50.33 & 42.80 & 46.33 & 48.51 & 41.33 & 54.07 & 36.67 & 59.25 \\
\hline 10 & Control & 86.00 & 0.00 & 88.00 & 0.00 & 90.00 & 0.00 & 90.00 & 0.00 & 90.00 & 0.00 \\
\hline & $\operatorname{SEm}( \pm)$ & 0.69 & & 0.62 & & 0.72 & & 0.53 & & 0.67 & \\
\hline & C.D at $5 \%$ & 2.05 & & 1.87 & & 2.15 & & 1.58 & & 1.99 & \\
\hline
\end{tabular}


Table.3 In-vivo evaluation of bio-products, plant extracts and fungicides against Alternaria cucumerina var. cyamopsidis

\begin{tabular}{|c|c|c|c|c|c|}
\hline \multirow[t]{2}{*}{ S.NO } & \multirow[t]{2}{*}{ FUNGICIDE } & \multicolumn{2}{|c|}{45 DAI } & \multicolumn{2}{|c|}{60 DAI } \\
\hline & & $\begin{array}{l}\text { Disease } \\
\text { intensity } \\
\text { per cent }\end{array}$ & $\begin{array}{l}\text { Disease } \\
\text { control } \\
\text { per cent }\end{array}$ & $\begin{array}{l}\text { Disease } \\
\text { intensity } \\
\text { per cent }\end{array}$ & $\begin{array}{l}\text { Disease } \\
\text { control } \\
\text { per cent }\end{array}$ \\
\hline 1 & Neem leaf extract & $\begin{array}{c}26.46 \\
(30.49)^{*}\end{array}$ & 53.30 & $\begin{array}{c}30.50 \\
(33.49)^{*}\end{array}$ & 51.06 \\
\hline 2 & Garlic bulb extract & $\begin{array}{c}21.36 \\
(27.51)^{*}\end{array}$ & 62.30 & $\begin{array}{c}25.83 \\
(30.53)^{*}\end{array}$ & 58.55 \\
\hline 3 & Neem oil & $\begin{array}{c}29.96 \\
(31.26)^{*}\end{array}$ & 48.18 & $\begin{array}{c}33.33 \\
(35.24)^{*}\end{array}$ & 46.52 \\
\hline 4 & Cow urine & $\begin{array}{c}39.35 \\
(38.81)^{*}\end{array}$ & 30.58 & $\begin{array}{c}40.26 \\
(39.35)^{*}\end{array}$ & 35.40 \\
\hline 5 & $\begin{array}{l}\text { Carbendazim 12\% + } \\
\text { Mancozeb 63\%WP }\end{array}$ & $\begin{array}{c}12.56 \\
(20.74)^{*}\end{array}$ & 77.83 & $\begin{array}{c}18.53 \\
(25.44)^{*}\end{array}$ & 70.27 \\
\hline 6 & Difenconazole (25EC) & $\begin{array}{c}16.10 \\
(23.63)^{*}\end{array}$ & 71.58 & $\begin{array}{c}17.83 \\
(24.93)^{*}\end{array}$ & 71.39 \\
\hline 7 & $\begin{array}{l}\text { Tebuconazole } 50 \%+ \\
\text { Trifloxystrobin } 25 \%\end{array}$ & $\begin{array}{c}21.60 \\
(27.68)^{*}\end{array}$ & 61.87 & $\begin{array}{c}24.40 \\
(29.58)^{*}\end{array}$ & 60.85 \\
\hline 8 & Chlorothalonil (75WP) & $\begin{array}{c}17.20 \\
(24.48)^{*}\end{array}$ & 69.64 & $\begin{array}{c}21.26 \\
(27.79)^{*}\end{array}$ & 65.08 \\
\hline 9 & Azoxystrobin & $\begin{array}{c}18.40 \\
(25.38)^{*}\end{array}$ & 67.52 & $\begin{array}{c}22.80 \\
(28.50)^{*}\end{array}$ & 63.42 \\
\hline 10 & Control & $\begin{array}{c}56.66 \\
(48.23)^{*}\end{array}$ & 0.00 & $\begin{array}{c}62.33 \\
(52.12)^{*}\end{array}$ & 0.00 \\
\hline & $\operatorname{SEm}( \pm)$ & 0.72 & & 0.94 & \\
\hline & C.D. at 5\% & 2.14 & & 2.81 & \\
\hline
\end{tabular}

*Value parenthesis are angular transformed 
Fig.1
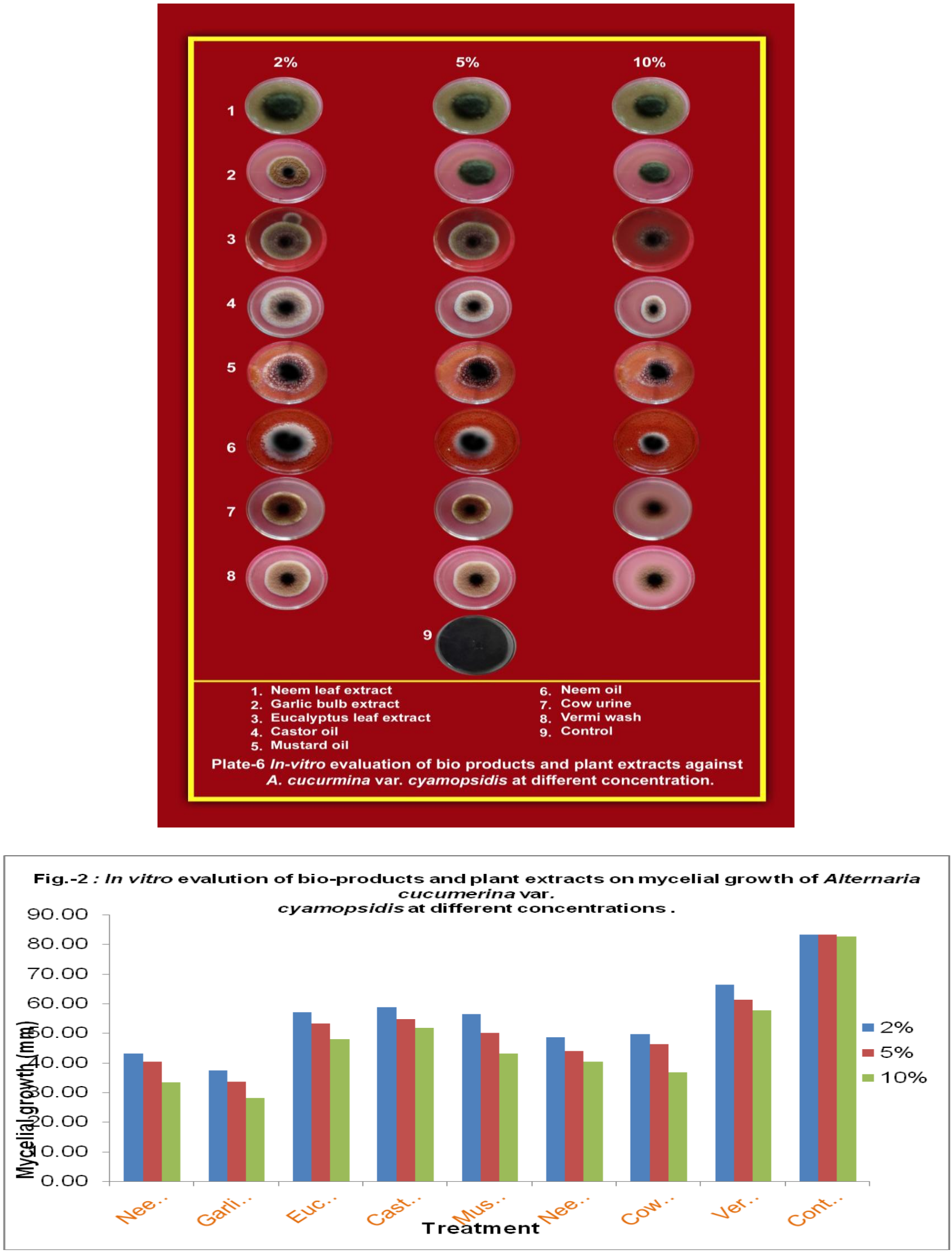

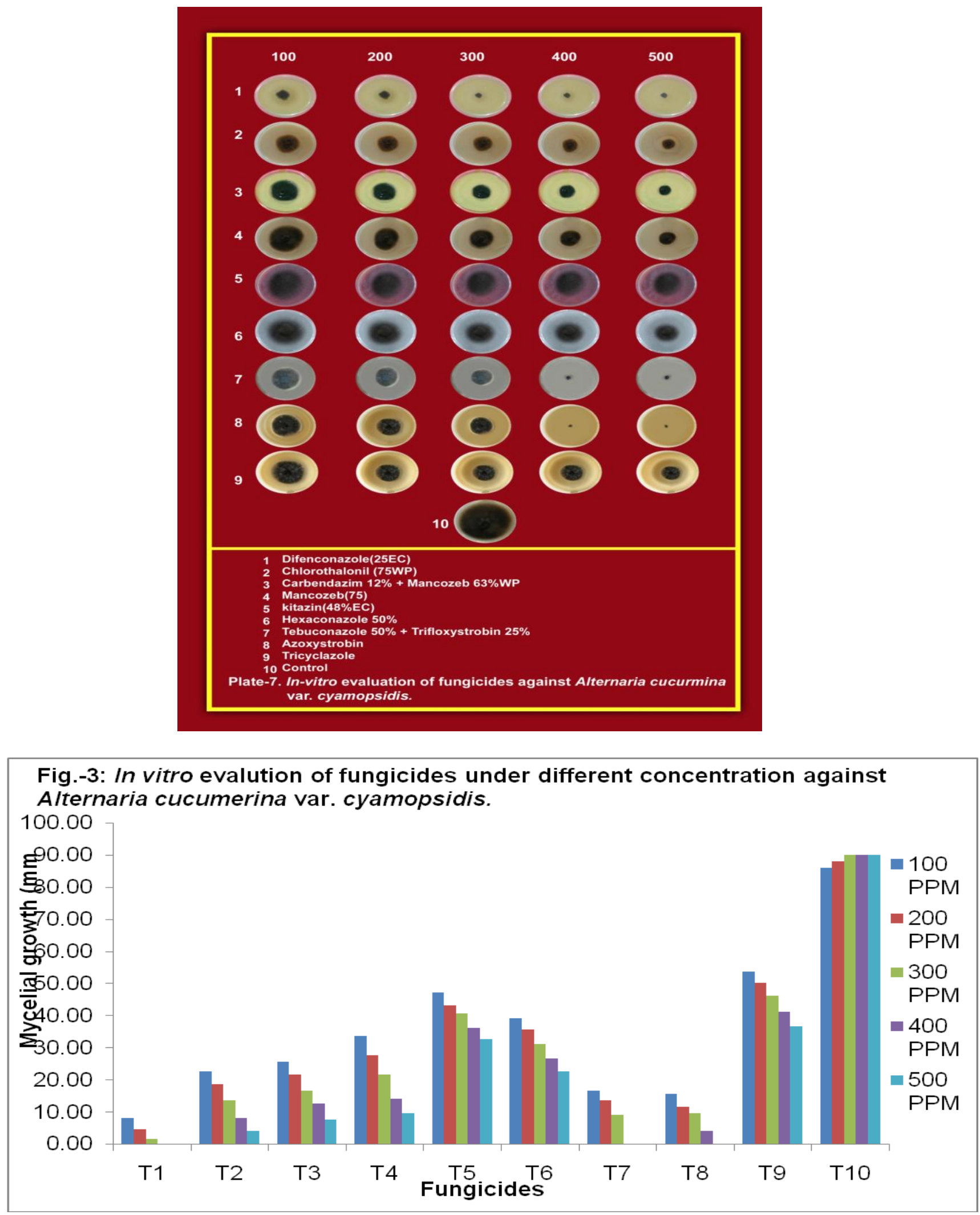
Out of eight botanical and plant extract and bio-products against Alternaria cucumerina var. cyamopsidis under in-vitro condition at $(2,5,10 \%)$ concentration the minimum growth of fungus was recorded in Garlic bulb extract at all concentration. which was significantly superior over rest of the plant extract in respect of mycelium growth. While maximum growth was recorded in vermi wash among the all eight botanical and bioproducts. The plant extracts showed antifungal activity and can be used in control of fungus associated with cluster bean. Similar results were reported by Kumar et al., (2005); Govindachari et al., (1998). Easier workers have also found garlic clove extract to be effective against growth and or conidial germination of Alternaria spp. Mishra and Gupta (2012) found that among plant extracts, clove extracts of Allium sativum at $10 \%$ resulted in maximum inhibition of growth of $A$. porriand $S$. vesicarium, respectively followed by Aloe vera at $10 \%$ concentration. Abd El-Ghanyet al., (2015) conducted that extracts of Azadirachta indica and Jatropha curcas were the most effective to inhibit the growth of the tested fungi. Different concentrations of plant extract of A. indica and of chemical fungicides were studied on the growth of Aspergillus flavus and Alternaria alternate. Findings from this study confirmed that plant extracts can be used as natural fungicides to control pathogenic fungi, thus reducing the dependence on the synthetic fungicides. Azadirachta indica extract, which was found to be the most efficient extract, might be a promising agent for controlling these fungi. Jhala et al., (2017) concluded that the Neem formulations Azadirachtin was found effective in vitro followed by garlic extract and Neem oil proved to be least inhibitor. Barros et al., (1995) reported inhibition of Alternaria alternate and A. longipes with bulb extracts of Garlic against mycelial growth. Antifungal properties in plant extracts plant extracts have also been observed against growth of $A$. alternate, $A$. brassicae, Colletotrichum capsici, Fusarium oxysporum, Rhizoctonia solani and Sclerotinia sclertiarum. Antifungal activites of extracts of Azadirachta indica, Ocimum santum, Allium cepa and A. sativum have also been reported by Shivpuri et al., (1997). Further studies are needed to isolate and characterize the antifungal moieties in these for practical disease control. Azadirachta indica, Allium capa and A. sativum showed antifungal property against Alternaria alternate. The extracts of Eucalyptus sp. And Calotropisprocera inhibited the growth of the fungus Shivpuri et al., (1997) studied the extracts of 10 plant species (Allium cepa, A.sativum, Azadirachta indica, Calotropis procera, Datura stramonium, Ocimum sanctum, Polyalthia longifolia, Tageteserecta, Vincarosea and Klithomia somnifera). These botanical showed fungitoxic properties against Alternaria and other pathogenic fungi. Allium sativum and Allium cepa brought about significant reduction in disease caused by alternaria leaf spot on the soyabean crop (Bhosale et al., 2014). Fungicide application can minimize disease and thus increase the genetic potential and ultimately yield. Therefore, it necessities the judicial use of fungicides at proper time.

In the present investigation nine fungicides tested under in-vitro condition at 100, 200, 300,400 and 500ppm all the tested fungicides were capable of inhibiting the growth of pathogen. However difenconazole causes minimum mycelium growth at all concentrations, which was followed by azoxtrobin and carbendazim $12 \%+$ manozeb $63 \%$ WP. Three fungicides namely Azoxystrobin, Tebuconazole + Trifloxystrobin and Difenconazole inhibited per cent mycelial growth at $500 \mathrm{ppm}$. Khan et al., (1995) also obtained a complete inhibition of A. alternata with propiconazole and tridemorph at 30ppm. Hexaconazole inhibited 
cent per cent growth of A. alternata (Dubey et $a l ., 2000)$. tridemorph was shown to be efficient in inhibiting the growth of $A$. alternate f.sp. Cucurbitae. Thiophanate methyl and carbendazim were found average in inhibiting the A. alternate. Khan et al., (1995) also reported significantly less mycelial growth of $A$. alternate in carbendazim and thiophanate methyl.

Among the fungicide plant extract and bioproducts under, field condition at 45 and 60 day after sowing the result reveals that all the plant extracts, bio-products and fungicide superior in checking disease. The minimum disease severity was recorded with difencozole at 45 and 60 DAI. Which was followed by Carbendazim $12 \%+$ Mancozeb63\% WP, Chlorothalonil, Azoxystrobin, Tebuconazole 50\%+ Trifloxystrobin 25\%, Garlic bulb extract, Tricyclazole. Among the botanical and bio products Garlic bulb extracts superior over rest of the botanical and bio-products. Among the fungicides tested under field conditions, the mixture azoxystrobin-difenconazole was the most effective in reducing Alternaria blight intensity (Kandolo et al., 2016). Devananthan and Ramanunjam (1995) observed a best control of $A$. solani by Mancozeb followed by chlorothalonil and copper oxychloride. Meena et al., (2010) observed that the disease intensity was significantly reduced by fungicide spray. The disease severity was low in treatments with Difenconazole and Chlorothalonil compared to that in control. Nimbecidine (Azadirachtin) spray treatment provided a good level of disease control (59\%). Treatments with aqueous leaf extract of Calotropis and Azadirachta as well as its seed kernel extract were also effective in controlling blight. The highest and significantly enhanced grain yield was with Difenconazole and the next best was with chlorothalonil. Azadirachtin, Calotropis leaf or Azadirachta seed kernel and leaf extracts also enhanced grain yields.

\section{References}

Abd El-Ghany, T., M. Roushdy, M. M., Mohamed, A. and Abboud, Al. (2015).Studies on efficacy of certain plant extracts as safe fungicides against phytopathogenic and mycotoxigenic Fungi. Agri. Bio. Sci. J. 1(3): 71-75.

Anonymous, (2017-18). Directorate of Agriculture. Agriculture Statistics. Government of Rajasthan, Jaipur.

Bhosale, Sri Kanth, B., Jadav, D.S., Patil, B.Y. and Chavan Ashok, M. (2014). Bio efficacy of plant extract on Alternaria leaf spot of soybean (Glycine max (L.) Merr). Indian J. Appl. Res., 411.

Dubey, A. K., Pandya, R. K., Bataria, A. M. and Srivastava, A. K. (2002). Efficacy of plant extracts against Alternaria tagetics. National Seminar on Role of Anti microbial for Sustainable Horticulture, January 20, 2002 at IGAU, Raipur (India). pp. 278.

Govindachari, T.R., Suresh, G., Geetha, Gopalakrishnan. Balaganesan, Banumathy and Masilamani, S. (1998). Identification of antifungal compounds from the seed oil of Azadirachta indica. Phytoparasitica. 26(2): 109-116.

Jhala, P., Mal, B. L. and Meena, M. K. (2017).Effective management of purple blotch of onion caused by Alternaria porri(Ellis) through host resistance, fungicides and botanicals. Int.J.Curr.Microbiol.App.Sci. $\quad$ 6(5): 1737-1745.

Kandolo, S.D., Thompson, A.H., Calitz, F.J., Laurie, S.M., Truter, M., Van Der, J.E., Waals and Aveling, T.A.S. (2016). Field tolerance of selected varieties and fungicide efficacy against Alternaria blight of sweet potato.African Crop Sci. J., 24(3): $331-339$.

Kumar Sanjeet; Upadhyay, J. P. and Kumar, Sanjeev. (2005). Evaluation of plant extract for control. J. Phytopathol. 7(2): 
166-168.

Meena A. K., Godara, S.L. and Gangopadhyay, S., (2010). Efficacy of fungicides and Plant Extracts against Alternaria Blight of Cluster bean. $J$. Mycol. Pl. Pathol. 40(2): 272-275.

Mishra, R. K. and Gupta, R. P. (2012).In vitro evaluation of plant extracts, Bio- agents and fungicides against purple blotch and stem phylium blight of onion. J. Med. Plant Res. 6(45): 5658-5661.

Nene YL, Thapliyal PN (1979).Fungicides in Plant Disease Control, Oxford and IBH Publishing House, New Delhi. pp. 163. of Alternaria Leaf spot of Viciafaba. Ann. Pl.
Protec. Sci., 13(1): 213-269.

Orellana, R. G. and Simmons, E.G. (1965).Alternaria blight of guar in the United States. Pl. Dis. Rep., 27: 129131.

Shivpuri.A. O.P. sharma and S.L. Jhamarina. (1997). Fungi toxic properties of plant extract against pathogenic fungi. J. Mycol. Pl. Pathol. 27: 29-31.

Swamy, Dhananjaya, P.S. and Naveena, K.P. (2015). An analysis of production performance and yield variability of guar (Cluster bean) in India. J. Prog. Agric., 6: 1.

\section{How to cite this article:}

Anupriya, Rajni Singh Sasode and Prahlad. 2020. Management of Alterneria cucumerina var. cyamopsidis through Plant Extracts, Bio products and Fungicides in-vitro and in-vivo. Int.J.Curr.Microbiol.App.Sci. 9(03): 2595-2605. doi: https://doi.org/10.20546/ijcmas.2020.903.297 